\title{
Taxes and their Effects on Business Environment
}

\author{
Valbona Zeqiraj
}

Artan Nimani

\section{Doi:10.5901/ajis.2015.v4n1p91}

\begin{abstract}
The paper is focused on the category of public finances, taxation, the description of the meaning, definition of their development and their role in business, goals, reasons for their collection, the basis on which it is made taxes, tax rates, classification, tax principles and effects and their impact on the analysis of taxes in general. Theory of tax analysis is defined by simplicity of economic development of a country, meeting the needs and demands of the citizens of that country in analogous manner, and determining the amounts of budget entry into that state. Taxes aimed at accumulating the necessary tools for the implementation of public expenditure. They vary from time to time and from place to place, they are numerous and varied where strategically are involved all classes of society. The importance of taxes has increased more and more in their historical development, the results have been expressed in the permanent extension of tax taxpayers, the number of tax types and growth of tax load. Free tax is mandatory and non-refundable in the state budget or in the budget of the local government, is set by law and is paid by any person exercising public rights or benefits of public service. Characteristic of tax liability means that tributary tax are obliged to pay tax, otherwise if they do not pay tax compulsory, cashing is done in violent manner. Tax liability arises when a person realizes income, when become a property owner or makes payments, which is subject of tax legislation. Taxes have a fundamental role in the construction of business reform and strategy, and as such is essential to the overall climate for doing business. The Government of Kosovo has undertaken a series of measures related to the business environment by eliminating a series of bureaucratic barriers, but has not substantially affected the tax base and has not properly oriented business climate, in an environment such as we are, in the process of creating and building the state and its institutions.
\end{abstract}

\section{Understanding, Definition and the Development of Tax}

Taxes are the main source of public revenue collection with which the state meets that public expenditures that are its competencies. The importance of taxation has always increased in their historical development. Taxes at the beginning of their appearance were as exceptional secondary entries for state, which are collected from a narrow group of people, which were collected from a narrow group of people, by which were meet the needs of state. While today are permanent entries, significant entries which are collected from natural persons (citizens) and legal entities, and which serve to finance large, numerous and diverse state costs. In the ancient state tax is explained as the giving of the submissive people to victorious people, and so the tax is identified with the submission. The tax is justified as the right of victorious people again submissive people. In early feudalism tax, initially was considered as gift later as aid, but it was with class character because has exacerbated more poor classes. In the capitalist system taxes experience a rapid development and are understood as regular income for the state. Different authors have given different definitions to the meaning of the tax, because taxes have changed depending on the existing conditions.

\section{Characteristics of Tax}

The main features of the tax are:

\subsection{Taxes are derivative entries}

Upon payment of the tax, the state realizes revenues, and for that amount of revenue, state decrease the wealth of individuals and legal entities. State by taxing business entities, he simultaneously reduces their economic power, in order to create economic force for himself and to secure its many financing costs. 


\subsection{Income taxes are mandatory}

By paying taxes its reduced economic power of those who pay the tax. The state does this in order to collect funds to meet the needs of the general public. Tax obligation cannot get away by subjects. Paying taxes is an obligation which does not depend on the wishes of individuals and legal entities, but is based on the financial sovereignty of the state and legal force.

\subsection{Taxes are collected to finance public spending}

With funds raised through tax expenditures state meets state expenditures.

\subsection{Taxes represent the provision, without direct counter remuneration}

There is no direct recompense, the state offers tax payers indirect benefits. This means that the person who pays tax is not entitled to seek direct counter remuneration. The funds collected from the tax are used to finance the duties of the state, i.e. expenses covers the costs of education, science, culture, health, sports, construction and maintenance of roads, railways, water supply, sewerage, National Defense, administration, courts, museums, theaters, internal security and integrity of borders, protection of water, air and land from pollution etc..

\subsection{Taxes do not have character for specific purpose}

The purpose of the tax is not determined previously. State income taxes are deposited to the state budget and serve to meet common needs (coverage of expenditures of the state).

\subsection{Taxes are collected in money}

Tax liability in modern states is determined with money, and completed in cash. In exceptional and rarely cases care covered in natural form or with work. Also, payment of tax is final and no refund provision, unlike some revenue (foreign), which are not final and they are returnable.

\subsection{Taxes are not linked with citizenship}

Characteristic of taxes is that they are not related to the citizenship which belongs the subjects of tax. The tax are mandatory for all persons in state territory and is based on financial sovereignty, taxes are mandatory obligation regardless of whether they are citizens of that state or not.

\section{Tax Purposes}

The purpose of taxation is to collect funds for the state and other public authorities, which are needed to finance their functions, this is the purpose of tax evasion.

In the slave states and the feudal states, the main purpose of the tax was to collect funds to meet the needs of the state, mainly the needs of the kings and the people of the royal court.

In capitalist countries tax purposes are not only fiscal, but also non-fiscal goals which are achieved through multiple goals of financial policy. So the task is not exclusively tax on realization of state funds, but now with the increasing number of taxpayers and increasing the number of types of tax, it has become possible to use taxes as a financial instrument for more efficient and flexible implementation of multiple goals of economic and social state.

In practice we can find the so-called restrictive and expansive tax policy. If the overall demand in the market is greater than the overall supply, is caused market disorder, so in these cases the restrictive tax policy measures influence in reducing the purchasing power of tributary tax, it also reduce the overall demand, so this tax policy is called restrictive tax policy. Conversely, if the overall market supply is greater than the overall demand. In that case should be taken measures to settle the spoiled balance and economic stability. In these cases with expansive tax policy measures affected the overall growth of the power that is directed towards increasing the purchasing power of tax tributary, and with it also to increase overall demand that is called expansive tax policy. Through tax policy can be implemented micro- 
economic-policies goals of the state and social goals.

- Price stability

- Full Employment

- Balanced balance of payments.

\section{Justification of Tax Collection}

Paying taxes means reducing economic power of tax tributary which worsens his financial situation. The most important theories associated with reviewing the problem of introducing the tax obligation and tax collection are:

1. Theory of power,

2. Theory of Price,

3. Theory of rendering tax,

4. Organic theory, and,

5. Social Theory.

\subsection{Theory of power}

This theory is based on the understanding that the payment of tax is justified by the right of the winner, which force the weak to pay tax.

\subsection{Price Theory}

According to this theory, taxes are the price for services that are performed by state in benefit of taxpayers. Therefore, by performing these services the state has certain costs which should be covered with the payment of tax. This theory is presented in many variants, as are:

a) The theory of insurance - according to which tax is the price (premium) which tributary tax, pays the state for their services which makes for personal and property security.

b) Satisfaction theory (the use of a right) - This theory is based on protecting the state borders and regulating the domestic order (courts, state administration, police), enables and ensures the taxpayers without paying taxes to use they wealth and incomes.

\subsection{Theory of tax reproduction}

This theory departs from the views that the costs of collecting the tax amounts should be sought justification for the existence of tax. The amount of tax to be spent, to carry out those state tasks and measures, that will affect the growth of national income, and increased income tax taxpayers. According to this theory with increasing income tax taxpayers, increase economic power, i.e. their tax power, and with it again grow the amount of tax collected.

\subsection{Organic theory}

The justification for the payment of tax by taxpayers, the organic theory seeks in the connection of state and its citizens. The justification of tax this theory finds on the necessity of the existence of the state and in the performance of its functions, so that taxes are the only option to cover the costs of the state and citizens.

\subsection{Social Theory}

Paying tax is the duty of every citizen in socialist countries. Any individual according to economic power - the size of the income and property value must participate in meeting the needs, namely the social outcomes. Largest revenue in socialism economy result from socialism (social sector), while only a small part of the from population gathered.

\section{Overview of the Business Sector in Kosovo}

Kosovo's economy since 1999, has been largely driven by international aid, remittances and public sector (World Bank, 
2010). The role of the private sector, especially the BVM-s has been relatively weak. Nevertheless, Kosovo is still in the transition phase, where entrepreneurship and small business creation is expected to play an important role in the path towards a modern economy and the free market, and therefore to the development and economic growth. Kosovo suffers from an imbalance of payments, where imports dominate exports significantly. This is mainly because of the fact that Kosovo BMV are not internationally competitive. BMV weak export inhibit further contribution of BMV - BPV, job creation and economic growth. Exports are dominated by base metals and minerals produced by major accounting companies. Due to the unfavorable environment for business and in the absence of creative entrepreneurial culture, Kosovo lacks innovative firms with rapid growth, which are major contributors to the creation of jobs in the western economies. Over $50 \%$ of all BMV operating in the commercial sector characterized by small investments and downtime. This pattern of copying the approach followed by "I" of new businesses, limiting the ability of SMBs sector to generate jobs. In terms of policy development, the report "SME Policy Index 2009" shows that Kosovo for several different reasons, is still in the stage of completion of basic requirements, institutional, legal and regulatory requirements relating to the policies of BMV.

\section{Business Environment and Legal Framework for BMV}

In EC Progress Report for Kosovo 2010 identified three main barriers faced by businesses in Kosovo. The first barrier is related to the unreliable supply of electricity and water that are especially serious for the BMV-productive. Also, as one of the main barriers to rapid development of SMBs is also given limited access to finance. The third barrier is insufficient rule of law, which affects all citizens of Kosovo.

Ministry of Trade and Industry, SMESA and Government in general have accepted that the removal of barriers for investment in business, growth and job creation needs more effort at all levels of government and the simplification of administration is key to promoting the development of SMBs sector. This is particularly important as regulatory and legislative barriers seem to have the greatest impact on BVM than in other businesses. Businesses in our country, there is no institutional support as have other countries in the EU or in the region, but nevertheless there though with a low level of economic operation.

\section{Conclusion}

In this article has been treated financial category - Taxes. Firstly are given different definitions of taxes and is doing a presentation and description of various forms of taxes and the effects that they have. Taxes are the main sources of public revenue collection, in which each country is meeting public expenses. We Can conclude that tax is the price, which every citizen pays to the state, thus increasing of tax represents the reduction of national revenue available for population. Reducing the national income, automatically brings reduction of personal consumption, that reflects the reduction of net national product and inclusion. Through tax policy, the restrictive and expansive, can be achieved economic and political goals of the state. Through tax policy, the restrictive and expansive, can be achieved economic and political goals of the state.

In the EC Progress Report for Kosovo 2010, were identified three main barriers faced by businesses in Kosovo. The first barrier is related to the unreliable supply of electricity and water that are especially serious for manufacturing of BMV. Also, as one of the main barriers to rapid development of BMV, is limited access to finance. The third barrier is the insufficient rule of law, which affects all citizens of Kosovo.

Given these recommendations, the Government of Kosovo (since 2010) has undertaken a series of measures related to the environment by eliminating bureaucracy barriers, but basically they did not affected tax base and they were not oriented properly in business climate beznesit, a ambijet as we are, in the process of creation and construction of the state and its institutions.

This is particularly important as regulatory and legislative barriers appear to have greater impact on economic development. Tax it reduces the taxable economic power. Once the tax is determined by legal provisions, the avoidance of tax represents a legal offense that is punishable. With tax policy measures affected the national economy, in international exchange, balance of payments, the redistribution of national income, accumulation and economic stability.

Our country has not been able yet to create a more friendly business climate, and especially not enough to harmonize fiscal policy and BMV developments.

In the future I consider as key recommendation would be scaling of the tax base and facilities in doing business, in particular by encouraging BMV with various subsidies or grants, as our approach to Kosovo in EU development funds, and other institutions is limited. 


\section{References}

Easterly, William (1999) 'Fiscal Illusion: Taking the Bite Out of Budget Cuts', Economic Policy, April.

Stiglitz, JE (2000) The Economics of the Public Sector, third edition, NeW York: WW Norton.

Bogt, H (2001) Politicians and output-oriented performance evaluation in municipalities, the European Accounting Review, vol. 10 No. 3 , Course Reader Public Financial Management Planning and Performance, Volume 2 pp 193

Orazem, P. and M. Vodopivec (1997): "Unemployment in Eastern Europe, value of human capital in transition to market: evidence from Slovenia", European Economic Review, Vol. 41, pp. 893-903.

Riinvest (2003): "Labour Market and Unemployment in Kosova", Riinvest Institute for Development Research, Prishtina.

Nimani, Dr Artan "Politikat Financiare" KUB \& ISRN Prishtine 2010

Riinvest (2004): "Education and economic development of Kosova", Research report, Riinvest Institute for Development Research, Prishtina, mimeo.

Riinvest Institute (2003): "Labour market and unemployment in Kosova", Research report, Riinvest, Prishtina.

SOK (2002): "Kosova Labour Force Survey 2001: Key Employment Indicators - December 2001", Statistical Office of Kosova (SOK) and the Ministry of Labour and Social Welfare (MLSW), Prishtina, Kosova, 26 June 2002.

Komani, Prof. Dr. Sabaudn"International monetary system'

Luboteni Dr. Gazmend "Banks Management and banking business

Komani, Dr. Sabudin "Finance" Prishtine 2010

\section{Other sources}

Insituti Riinvest

URL: www. riinvestinstitute. org

Ministria e Financave dhe Ekonomisë

URL: www. mfe-rks. org

Wikipedia

URL: www. wikipedia. org 
